\title{
ANALOG SHOCKING THERAPY SEBAGAI METODE KATARSIS TERHADAP KETENANGAN JIWA PADA KARYAWAN
}

\author{
Mohammad Aqil Baihaqi \\ UIN Sunan Gunung Djati Bandung \\ Email: radenabay123@gmail.com \\ Dian Siti Nurjanah \\ UIN Sunan Gunung Djati Bandung \\ Email: dianayusuf27@gmail.com \\ Medina Chodijah \\ UIN Sunan Gunung Djati Bandung \\ Email: medinachodijah@gmail.com
}

\begin{abstract}
This research is backed by the many problems experienced by employees who suffer from mental unrest that can inhibit the productivity of work in the scope of work especially in the company. The purpose of this research is to know the condition of the souls of employees, as well as the process in conducting Analog Shocking Therapy as a cathartic method, and to know the Analog Shocking Therapy as a cathartic method of the employee's mental tranquility. The method of study used is a method of mixture with an expressive sequential strategy, by taking and processing quantitative data first then deesed through a qualitative interview. The results obtained from this study showed that the low mental peace conditions experienced by employees before therapy using Analog Shocking Therapy as much as $51 \%$, the data showed that many employees experienced Low mental peace conditions. The stage in implementing Analog Shocking Therapy is that the client is invited to do a visualization by creating the parable of the ball as a medium to transfer the negative emotions that have been experienced. And Analog Shocking Therapy as a cathartic method of the peace of mind of the employees showed that experienced employees after the therapy experienced a change of self becomes more spirited, more optimistic, easier in controlling fear, worry, and anger at work..
\end{abstract}

Keywords:

Therapy, Catharsis, Emotion, Mental Tranquility, Employee

\begin{abstract}
Abstrak
Penelitian ini dilatarbelakangi oleh banyaknya permasalahan yang dialami para karyawan yang mengalami keresahan jiwa yang dapat menghambat produktivitas kerja dalam lingkup pekerjaan terutama di perusahaan. Tujuan penelitian ini untuk mengetahui kondisi ketenangan jiwa karyawan, serta proses dalam melakukan Analog Shocking Therapy sebagai metode katarsis, dan untuk mengetahui Analog Shocking Therapy sebagai metode katarsis terhadap ketenangan jiwa karyawan. Metode penelitian yang digunakan adalah metode campuran dengan strategi sekuensial eksplanatoris, yaitu dengan cara mengambil dan mengolah data kuantitatif terlebih dahulu kemudian diperdalam melalui wawancara kualitatif. Hasil yang diperoleh dari penelitian ini menunjukkan bahwasanya kondisi ketenangan jiwa yang dialami karyawan sebelum dilakukan terapi menggunakan Analog Shocking Therapy sebanyak 51\%, data tersebut menunjukkan bahwa banyak karyawan yang mengalami kondisi ketenangan jiwa yang rendah. Adapun tahapan dalam pelaksanaan Analog Shocking Therapy yaitu klien diajak untuk melakukan sebuah visualisasi dengan membuat perumpamaan benda berupa bola sebagai media untuk mentransfer emosi negatif yang dialaminya. Dan Analog Shocking Therapy sebagai metode katarsis terhadap ketenangan jiwa karyawan menunjukkan bahwa yang dialami karyawan setelah dilakukan terapi mengalami adanya perubahan diri menjadi lebih semangat, lebih optimis, lebih mudah dalam mengendalikan rasa takut, khawatir, dan marah saat bekerja.
\end{abstract}

Kata Kunci:

Terapi, Katarsis, Emosi, Ketenangan Jiwa, Karyawan

DOI: http://dx.doi.org/10.15575/saq.v4i2.7572 
Mohammad Aqil Baihaqi, Dian Siti Nurjanah, Medina Chodijah
Analog Shocking Therapy sebagai Metode Katarsis terhadap Ketenangan Jiwa Pada Karyawan

Received: 2020-01-20; Accepted: 2020-01-20 ; Published: 2020-01-29

\section{A. PENDAHULUAN}

Di era yang serba kompetitif ini menjadi sebuah tuntutan tersendiri bagi perusahaan yang berkembang agar mampu bersaing di masyarakat. Tuntutan-tuntutan tersebut muncul dan menjadi sebuah tekanan yang harus dihadapi oleh setiap individu yang berada dalam sebuah perusahaan atau lingkungan kerja. Tekanan-tekanan tersebut dapat memicu munculnya berbagai emosi negatif yang dapat mengganggu ketenangan jiwa karyawan dalam bekerja. Jiwa yang tidak tenang menyebabkan terhambatnya produktivitas dalam bekerja sehingga muncul berbagai perasaan negatif seperti emosi yang susah dikendalikan, rasa cemas, rasa takut, dan perasaan negatif lainya yang dapat terjadi karena adanya faktor stres dalam bekerja. Stres kerja adalah suatu kondisi yang dapat memengaruhi emosi, cara berpikir, dan kondisi psikologis seseorang. Stres yang terlalu berat dapat mengancam kemampuan produktivitas seseorang dalam melaksanakan berbagai pekerjaanya sehingga sangat berpengaruh terhadap prestasi kerjanya. ${ }^{1}$

Menurut para salafus shalih, perasaanperasaan negatif yang muncul seperti rasa cemas, khawatir, dan takut itu merupakan sinyal yang diberikan Allah sebagai tanda bahwa adanya jiwa yang tidak tenang dan mengalami penurunan tingkat keimanan dalam diri seseorang. Menurut para salafus shalih, bagi orang-orang yang berpegang teguh dan yakin bahwa Allah adalah Dzat yang maha melindungi, menjamin, dan mencukupi segala kebutuhanya di dunia maka ia akan terhindar dari berbagai perasaan negatif yang menyebabkan munculnya keresahan jiwa dalam kehidupanya. ${ }^{2}$

Menurut Syamsu Yusuf, stres dapat membawa pengaruh positif maupun negatif terhadap kehidupan setiap individu. Pengaruh positifnya yaitu mendorong individu untuk

\footnotetext{
${ }^{1}$ Noor 'Aini Aslihah, Pengaruh Stres Kerja Terhadap Kinerja Karyawan di Koperasi Syari'Ah Binama Semarang, (Semarang : Universitas Islam Negeri Walisongo, 2015), ix

${ }^{2}$ Ahmad Barozi dan Abu Azka Fatin, Penyakit Hati dan Penyembuhanya, (Jogjakarta : Darul Hikmah, 2008), 44
}

melakukan sesuatu, melatih pikiran kreatif untuk mencari solusi terhadap suatu permasalahan, memunculkan kesadaran diri, dan mendapatkan pengalaman baru. Sedangkan pengaruh negatifnya adalah menimbulkan berbagai perasaan negatif, perasaan tidak percaya diri, penolakan, marah, atau depresi, atau depresi yang dapat memicu terjangkitnya berbagai penyakit seperti insomnia, sakit kepala, tekanan darah, maag dan lain-lain. ${ }^{3}$

Oleh karena itu, untuk mengatasi munculnya jiwa yang tidak tenang yang dapat menghambat produktivitas karyawan yang muncul akibat adanya faktor stres dalam bekerja dapat diatasi dengan berbagai cara seperti halnya menurut Imam al-Ghazali yaitu dengan tazkiyatun nafs, yaitu sebuah upaya mengembalikan jiwa seseorang kedalam fitrahnya atau kesucian jiwa sehingga mendapatkan kondisi jiwa yang tenang. ${ }^{4}$

Selain itu, cara yang dapat dilakukan untuk mendapatkan ketenangan jiwa yaitu dengan cara menghilangkan berbagai permasalahan yang dapat mengakibatkan jiwa tidak tenang. Salah satu faktor keresahan jiwa yang dialami karyawan adalah adanya faktor stres kerja. Sehingga untuk menurunkan perasaan negatif akibat adanya stres kerja dapat menggunakan berbagai teknik psikologi, salah satu teknik yang dapat digunakan untuk menurunkan stres dalam bekerja dapat menggunkan teknik “Analog Shocking Therapy”. Oleh karena itu, pada penelitian ini peneliti mengangkat sebuah penelitian yang berjudul "Analog Shocking Therapy sebagai Metode Katarsis terhadap Ketenangan Jiwa Pada Karyawan”.

\section{B. PEMBAHASAN}

\section{Pengertian Katarsis}

Katarsis adalah sebuah bentuk ekspresi terhadap pelepasan emosi yang dirasakan seseorang. Katarsis terkadang disamakan

\footnotetext{
Syamsu Yusuf, Mental Hygiene : Perkembangan Kesehatan Mental dalam Kajian Psikologi dan Agama. (Bandung : Pustaka Bani Quraisy,2004), 90-91

${ }^{4}$ Abd Syakur, Metode Ketenangan Jiwa, (Surabaya : Fakultas Dakwah IAIN Sunan Ampel,2007), 172
} 
Mohammad Aqil Baihaqi, Dian Siti Nurjanah, Medina Chodijah

dengan abreaksi yang didefinisikan sebagai bentuk luapan emosi seseorang yang menyakitkan dengan melibatkan kesadaran. Istilah katarsis ini berasal dari Bahasa Yunani yaitu "kathoros" yang berarti "untuk menyucikan" atau "untuk membersihkan". Istilah ini banyak digunakan dalam berbagai bidang keahlian, salah satunya adalah bidang psikologi. Berdasarkan teori Sigmund Freud menjelaskan bahwa katarsis mampu melepaskan rasa sakit di masa lalu dengan cara meluapkan rasa sakitnya tersebut secara menyeluruh. Dalam ruang lingkup religius, katarsis dapat diartikan sebagai pengalaman transenden yang digunakan untuk membersihkan jiwa. ${ }^{5}$

Konsep teori katarsis berdiri diatas teori psikoanalisa Sigmund Freud, ia berpandangan bahwasanya emosi yang tertahankan di alam bawah sadar dapat menyebabkab ledakan emosi yang berlebih, sehingga diperlukan sebuah penyaluran terhadap emosi yang tertahan di alam bawah sadar tersebut. Dan penyaluran emosi yang tertahan di alam bawah sadar secara konstruktif tersebut disebut dengan katarsis.

\section{Analog Shocking Therapy sebagai Metode Katarsis}

Analog Shocking Therapy adalah sebuah teknik sebagai metode katarsis untuk meluapkan berbagai perasaan negatif dengan cara menyalurkan emosi dan agresi berupa kekecewaan, kesedihan, kekesalan, dan lain sebagainya. Hal ini perlu diperhatikan karena perasaan emosi negatif tersebut merupakan bentuk adanya keresahan jiwa yang dialami seseorang, terutama bagi seorang karyawan. Kehidupan yang sangat dinamis mengantarkan manusia pada pola kehidupan yang sangat kompleks yang dapat membawa manusia berhadapan dengan berbagai keterbatasan yang dimilikinya. ${ }^{6}$

\footnotetext{
5 Sri Wahyuningsh, Teori Katarsis dan Perubahan Sosial, ( Universitas Trunojoyo Madura Fakultas Ilmu Sosial dan Ilmu Budaya : 2017 ), 40

${ }^{6}$ Sri Wahyuningsih, Teori Katarsis dan Perubahan Sosial, ( Madura. Universitas Trunojoyo Madura Fakultas Ilmu Sosial dan Ilmu Budaya Prodi Ilmu Komunikasi : 2017 ), 41
}

Analog Shocking Therapy sebagai Metode Katarsis terhadap Ketenangan Jiwa Pada Karyawan

Analog Shocking Therapy mengadopsi dari teknik Neuro-Linguistic Programming yaitu Editing Sub-Modality Intervention. Menurut Teddi Prasetya Neuro-Linguistic Programming (NLP) berkutat pada sebuah perubahan diri. Perubahan yang dilakukan pada pendekatan NLP ini dilakukan dengan cara sebuah intervensi (Programming) terhadap sebuah program yang ada didalam pikiran (Neuron) dengan menggunakan sebuah pola bahasa (Linguistic). ${ }^{7}$ Dikatakan intervensi karena dalam NLP berasumsi bahwa setiap manusia memiliki program masing-masing yang terbentuk melalui faktor genetik maupun faktor pengalaman hidup.

Disebut dengan "Analog” dikarenakan dalam proses terapinya dilakukan dengan cara meningkatkan intensitas emosi secara bertahap (gradual). 8 Dan kata "Shocking" menunjukan adanya kejutan saat melakukan terapi, hal ini bertujuan untuk menembus critical area. Critical area disebut sebagai koordinasi respons terhadap stimulus dunia luar, serta fokus perhatian manusia. ${ }^{9}$

Teknik yang digunakan saat melakukan terapi adalah sebagai berikut:

1. Pre Talk: Bertujuan untuk membangun rapport sebelum pelaksanaan terapi. Dalam sesi ini terapis menggali permasalahan yang dialami oleh klien sehingga dalam sesi ini, terapis perlu mengetahui emosi negatif apa yang dialami klien yang dapat menghambat produktivitas diri. Dalam tahapan ini juga, terapis perlu mengetahui tingkat intensitas emosi negatif yang dialami klien sebagai tolak ukur untuk menurunkan emosi negatif.

Rapport sejatinya adalah hasil. Dan proses untuk mencapainya disebut dengan pacing, alias penyelarasan. Dua orang yang berkomunikasi biasanya berada pada frekuensi yang berbeda, sampai mereka

${ }^{7}$ Teddi Prasetya, NLP The Art of Enjoying Life: Kiat Sederhana Mengelola Pikiran untuk Hidup Bahagia, ( Jakarta : Serambi Ilmu Semesta, 2014 ), 28

${ }^{8}$ Yan Nurindra, Modul Neo NLP Practitioner, ( Jakarta : Neo NLP Society, 2015 ), 17

${ }^{9}$ Eric Siregar, Dahsyatnya kata-kata: Menghipnosis itu Sangat Mudah, ( Jakarta : Salaris Publisher, 2014 ), 11 
Mohammad Aqil Baihaqi, Dian Siti Nurjanah, Medina Chodijah

menyelaraskan diri, hingga akhirnya dapat menghasilkan obrolan yang mengalir dengan lancar. ${ }^{10}$

2. Tawakkal method: merupakan tahap yang dilakukan sebelum pelaksanaan terapi. Dalam sesi ini klien diajak untuk benarbenar mengikhlaskan permasalahan yang dialaminya dengan cara pasrah total kepada Allah. Tujuan utama tahap ini adalah untuk berdoa dan menumbuhkan self-awareness kepada sang pencipta.

Gambaran teguhnya hati seorang individu yang hanya menambatkan dirinya kepada Allah disebut tawakal. Tokoh sufi yang menghubungkan term tawakal kepada istilah tauhid salah satunya adalah Al-Ghazali. Tauhid menjadi pondasi yang kokoh bagi tawakal.. sedangkan Dzun Nun memiliki pandangan tawakal dengan menyatakan bahwa diri sendiri berikut kekuatanya tidak perlu dipikirkan. Ini menyataka bahwa substansi tawakal adalah totalitas penyerahan diri hanya kepada Allah.. ${ }^{11}$

3. Create Ball: Setelah klien berdoa untuk memasrahkan dirinya kepada Allah atas permasalahan atau emosi negatif yang dialaminya. Barulah kita sebagai terapis membuat sebuah analogi bola seperti halnya memegang bola menggunakan kedua tangan dihadapan klien sebagai metode untuk menyalurkan perasaan negatif yang dialami klien. Dalam pikiran klien, klien perlu melakukan imajinasi terhadap bola yang dibuat terapis. Setelah bola tersebut tergambar dalam pikiran klien, selanjutnya klien diajak untuk meinyalurkan semua perasaan negatif ke dalam bola tersebut.

Penyaluran tersebut dalam psikoanalisa disebut sebagai metode katarsis. Tujuan menyalurkan emosi negatif ini adalah untuk mengubah makna atau pengalaman yang tidak diinginkan. Hal ini dalam

\footnotetext{
${ }^{10}$ Teddi Prasetya, NLP The Art of Enjoying Life: Kiat Sederhana Mengelola Pikiran untuk Hidup Bahagia, ( Jakarta : Serambi Ilmu Semesta, 2014 ), 151

${ }^{11}$ M. Solihin, Tasawuf Tematik : Membedah Tema-tema Penting Tasawuf, ( Bandung : CV. Pusataka Setia, 2003 ), $21-22$
}

Analog Shocking Therapy sebagai Metode Katarsis terhadap Ketenangan Jiwa Pada Karyawan

Neuro-Linguistic Programming biasa disebut dengan istilah Critical Driver atau Driver Submodality. ${ }^{12}$

4. Bola membesar: Ketika klien sedang menyalurkan perasaan emosi negatifnya tersebut. Kita sebagai terapis akan memperbesar bolanya dengan gerakan tangan, bolanya dapat membesar mengikuti perasaan negatif yang disalurkan. Hal ini seperti halnya kita memegang bola dan mempompanya hingga membesar menggunakan angin. Namun dalam hal ini, bola membesar dengan dipompa menggunakan perasaan negatif yang disalurkan.

Hal ini bertujuan untuk melakukan editing submodalities, karena mengubahubah submodalitas merupakan salah satu cara terbaik untuk mengubah makna, meredakan ketakutan, phobia, meningkatkan motivasi, hingga menghilangkan keyakikan (belief) yang keliru. $^{13}$

5. Bola diperkecil: Setelah semua perasaan negatif tersebut disalurkan ke bola yang telah dibuat tadi hingga bolanya membesar. Baru langkah yang dilakukan selanjutnya adalah memperkecil bolanya. Tugas kita sebagai terapi adalah menekan sekuat tenaga mengecilkan bola tersebut. Semakin kita tekan bolanya maka semakin mengecil pula perasaan negatif yang dialami klien. Kita perlu menekan bola tersebut secara pelan-pelan dan merasakan tekanan bola tersebut. Saat bola ditekan, kita perlu memberikan kalimat sugesti yang diulang-ulang, seperti "semakin saya perkecil bola ini maka semakin mengecil pula perasaan yang anda rasakan" kalimat ini diulangulang sambil memperkecil bola nya.

Dalam Neuro-Linguistic Programming jika kita memberikan perhatian lebih pada konteks dan struktur dari internal representation (IR) dibanding pada kontenya. Hal ini menunjukkan bahwa dengan mengubah submodalitas kita juga

\footnotetext{
12 Yan Nurindra, Modul Neo NLP Practitioner, ( Jakarta : Neo NLP Society, 2015 ),19

${ }^{13}$ Yan Nurindra, Modul Neo NLP Practitioner, 17
} 
akan mengubah struktur-strukur dari pengalaman tersebut. Dengan kata lain, jika kita mengubah struktur tersebut, maka maknanyapun akan berubah. ${ }^{14}$

6. Shocking method: Yaitu tahapan memberikan efek kejut kepada klien. Efek kejut tersebut dilakukan saat klien sedang benar-benar fokus melihat dan merasakan bolanya diperkecil yang dapat memperkecil perasaan negatifnya. Saat kita memperkecil bolanya dan klien sedang fokus, barulah kita memberikan efek kejut secara tiba-tiba dengan cara memberikan tepukan tangan yang disertai dengan sugesti positif seperti kata-kata "sembuh, sehat, segar, nyaman, dan lainlainl".

7. Tarikan nafas: Setelah memberikan efek kejut, klien diajak untuk menarik nafas secara perlahan-perlahan untuk membuat kondisi yang nyaman dan rileks dalam diri klien. Teknik nafas dalam tujuan relaksasi bertujuan untuk meningkatkan ventilasi alveoli, memelihara pertukaran gas, mengurangi stres fisik maupun emosional yaitu dapat menurunkan rasa nyeri dan dapat menurunkan perasaan kecemasan. Sedangkan manfaat lain yang dapat dirasakan oleh klien adalah dapat menghilangkan rasa nyeri, berkurangnya rasa gelisah, dan ketentraman hati. ${ }^{15}$

8. Langkah terakhir adalah mengucapkan hamdalah. Sebagai bentuk terima kasih kepada Allah sebagai Dzat yang memberikan ketenangan jiwa.

9. Ulangi 2-3 kali untuk membuat efek terapi yang lebih optimal.

10. Tanyakan intensitas penurunan emosi negatif yang dialami klien.

\section{Pengertian Ketenangan Jiwa}

Secara etimologi kata jiwa berasal dari kata "psyche" yang berarti jiwa atau nyawa. Sedangkan kata jiwa dalam psikologi sufi yang digunakan adalah "an-nafs". Istilah ini

\footnotetext{
${ }^{14}$ Yan Nurindra, Modul Neo NLP Practitioner, 17

15 Muhamad Arfa, Pengaruh Teknik Relaksasi Nafas Dalam Terhadap Penurunan Nyeri Pada Pasien PostOperasi Appendisitis, ( Gorontalo : Universitas Negeri Gorontalo, 2013 ), -
}

seringkali diterjemahkan sebagai "ego" atau "jiwa". Makna lain dari kata nafs adalah "intisari" atau juga berarti "napas". Kata nafs dalam bahasa Arab seringkali digunakan sebagai "diri" yakni dalam penggunaan bahasa sehari-hari, seperti "nafsi" yang berarti diriku atau "nafsaka" yang berarti dirimu. Banyak para sufi yang menulis kata nafs yang cenderung mengarah pada sifat-sifat dan perilaku buruk manusia. Pada tingkatan terendah nafs dapat membawa ke arah keburukan atau kesesatan. ${ }^{16}$

Zakiyah Darajat menggunakan istilah ketenangan jiwa dan kesehatan mental dalam pengertian yang sama. Beliau berpendapat bahwa ketidaktenangan hati, atau kurangnya sehat mental dapat memengaruhi tingkah laku seseorang. Manusia yang memiliki jiwa yang tenang akan senantiasa merasa bahwa dirinya selalu berada dalam lindungan Allah Swt, ia akan lebih banyak menginginkan hal-hal yang bersifat ruhaniah yang dapat menumbuhkan ketenangan jiwa dalam dirinya. Sehingga ia akan mendapatkan kemuliaan hidup dengan selalu merasa ridho terhadap segala sesuatu yang dilakukanya guna untuk mendapatkan ridho-Nya Allah Swt. ${ }^{17}$ Jiwa yang tenang merupakan suatu keadaan tertinggi terhadap perkembangan spiritual yang dialami seseorang. Jiwa yang tenang berada dalam keadaan yang harmonis, nyaman, damai, dan bahagia. Jiwa yang tenang akan selalu melakukan penyucian diri terhadap berbagai tekanan yang muncul dari pertarungan atas kendala yang menghalangi antara pikiran dan perasaan. ${ }^{18}$

Menurut para salafus shalih, perasaanperasaan negatif yang muncul seperti rasa cemas, khawatir, dan takut itu merupakan sinyal yang diberikan Allah sebagai tanda bahwa adanya jiwa yang tidak tenang dan mengalami penurunan tingkat keimanan

\footnotetext{
${ }^{16}$ Robert Frager, Psikologi Sufi untuk Trnasformasi : Hati, Diri dan Jiwa, ( Jakarta : PT. Serambi Ilmu Semesta, 2002 ), 86

17 Zakiah Daradjat, Kesehatan Mental, ( Jakarta : Gunung Agung, 1983 ), 22

18 Tika Saripah, dkk. Fungsi Zuhud Terhadap Ketenangan Jiwa, ( Bandung : Fakultas Ushuluddin UIN Sunan Gunung Djati Bandung, 2017 ), 143-144
} 
Mohammad Aqil Baihaqi, Dian Siti Nurjanah, Medina Chodijah

dalam diri seseorang. Sehingga Allah memanggil hamba-Nya sebagaimana firmanNya dalam Al-Qur'an surat Al-Fajr ayat 2728, yang artinya: "Wahai jiwa yang tenang! Kembalilah pada Tuhanmu dengan hati yang ridho dan di ridhoi-Nya". Sebab menurut para salafus shalih, bagi orang-orang yang berpegang teguh dan yakin bahwa Allah adalah Dzat yang maha melindungi, menjamin, dan mencukupi segala kebutuhanya di dunia maka ia akan terhindar dari berbagai perasaan negatif yang menyebabkan munculnya keresahan jiwa dalam kehidupanya. ${ }^{19}$

Ketenangan jiwa merupakan suatu hal yang sangat diinginkan oleh banyak orang. Terutama bagi seorang karyawan yang menginginkan sebuah pekerjaan yang nyaman dan menikmati berbagai pekerjaan yang dilakukan. Sebab, jiwa yang tidak tenang akibat adanya suatu tuntutan pekerjaan yang berlebihan, target yang harus dicapai sedangkan kapasitas diri kurang memadai, permasalahan internal seperti adanya tim kerja yang bermasalah, serta berbagai hal lainya yang menyebabkan seorang karyawan tidak menikmati apa yang sedang dilakukan, bahkan akibat adanya tuntutan yang berlebihan tersebut menjadikan seorang karyawan mengalami permasalahan kesehatan badaniyah, seperti maagh, asam lambung, sakit kepala, dan lain sebagainya. Kondisi jiwa akibat adanya pergolakkan batin yang dialami karyawan ini terjadi akibat banyaknya tuntutan pekerjaan yang menjadi keresahan tersendiri bagi seorang karyawan dalam bekerja dan dapat menghambat produktivitasnya dalam bekerja.

\section{HASIL PENELITIAN}

\section{a. Kondisi Ketenangan Jiwa Karyawan Secara Umum}

Analisis deskriptif statistik dimaksudkan untuk mengetahui distribusi frekuensi dari jawaban responden terhadap angket yang disebarkan. Dalam deskripsi ini digunakan pula kelas interval dengan kategori rendah dan tinggi. Kelas interval digunakan untuk melihat responden yang memiliki ketenangan jiwa tinggi dan rendah.

Berdasarkan hasil penelitian yang dilakukan pada subyek dengan menggunakan alat ukur ketenangan jiwa yang terdiri dari 28 item yang teruji validitasnya, perhitungannya dapat dilihat pada table dibawah ini.

Tabel 1.4 Deskripsi Data Ketenangan Jiwa Secara Umum

\begin{tabular}{|l|l|l|l|l|}
\hline Indikator & $\begin{array}{c}\text { Nilai } \\
\text { maksim } \\
\text { al }\end{array}$ & $\begin{array}{c}\text { Nilai } \\
\text { minim } \\
\text { al }\end{array}$ & $\begin{array}{c}\text { Mea } \\
\mathrm{n} \\
\text { empi } \\
\text { ris }\end{array}$ & $\begin{array}{c}\text { Stand } \\
\text { ar } \\
\text { devia } \\
\text { si }\end{array}$ \\
\hline $\begin{array}{l}\text { Ketenang } \\
\text { an jiwa }\end{array}$ & 159 & 110 & $\begin{array}{l}134, \\
5\end{array}$ & 8,1 \\
\hline
\end{tabular}

Nilai maksimal diperoleh dari nilai tertinggi dari total keseluruhan item yang dijawab subyek, nilai minimal diperoleh dari nilai terendah dari total keseluruhan item yang dijawab subjek. Mean empiris diperoleh dari nilai maksimal ditambah nilai minimal dibagi dua sehingga menghasilkan 134,5. Standar deviasi diperoleh dari nilai maksimal dikurangi nilai minimal dibagi 6 sehingga menghasilkan 8,1 .

Berdasarkan nilai diatas maka dapat diperoleh kategori tingkat ketenangan jiwa sebagai berikut.

Tabel 2.4 Kriteria Tingkat Ketenangan Jiwa Karyawan

\begin{tabular}{|l|l|l|}
\hline \multicolumn{1}{|c|}{ Kategori } & \multicolumn{1}{|c|}{$\begin{array}{c}\text { Rumus } \\
\text { interval }\end{array}$} & \multicolumn{1}{|c|}{$\begin{array}{c}\text { Hasil } \\
\text { interval }\end{array}$} \\
\hline Rendah & $\mu-3 \sigma \leq X$ & $110,2 \leq X$ \\
& $<\mu$ & $<134,5$ \\
\hline Tinggi & $\begin{array}{l}\mu \geq X \geq(\mu \\
+3 \sigma)\end{array}$ & $\begin{array}{l}134,5 \geq X \\
\geq 158,8\end{array}$ \\
\hline
\end{tabular}

Berdasarkan hasil perhitungan dan pengukuran subjek penelitian dengan menggunakan alat ukur pola ketenangan jiwa, maka didapat jumlah skor yang dapat digambarkan melalui tabel sebagai berikut :

\footnotetext{
19 Ahmad Barozi dan Abu Azka Fatin, Penyakit Hati dan Penyembuhanya, (Jogjakarta : Darul Hikmah, 2008), 44
} 
Mohammad Aqil Baihaqi, Dian Siti Nurjanah, Medina Chodijah

Tabel 3.4 Perhitungan Tingkat Ketenangan Jiwa Karyawan

\begin{tabular}{|l|l|l|l|l|}
\hline $\begin{array}{l}\text { Katego } \\
\text { ri }\end{array}$ & $\begin{array}{l}\text { Rumu } \\
\text { s } \\
\text { interv } \\
\text { al }\end{array}$ & $\begin{array}{l}\text { Hasil } \\
\text { interv } \\
\text { al }\end{array}$ & $\begin{array}{l}\text { Frekuen } \\
\text { si }\end{array}$ & $\begin{array}{l}\text { Presenta } \\
\text { se }\end{array}$ \\
\hline $\begin{array}{l}\text { Renda } \\
\text { h }\end{array}$ & $\begin{array}{l}\mu-3 \sigma \\
\leq X< \\
\mu\end{array}$ & $\begin{array}{l}110,2 \\
\leq X< \\
134,5\end{array}$ & 15 & $51 \%$ \\
\hline Tinggi & $\begin{array}{l}\mu \geq X \\
\geq(\mu \\
+3 \sigma)\end{array}$ & $\begin{array}{l}134,5 \\
\geq X \geq \\
158,8\end{array}$ & 14 & $49 \%$ \\
\hline \multicolumn{3}{|l|}{ Jumlah } & 29 & $100 \%$ \\
\hline
\end{tabular}

Berdasarkan data pada tabel di atas dapat diketahui bahwa ketenangan jiwa karyawan dalam kategori rendah yaitu sebanyak 51\% dan kategori tinggi sebanyak 49\%. Dengan demikian ketenangan jiwa pada karyawan tergolong dalam kategori rendah.

\section{Gambar 1.4 Grafik Kondisi Ketenangan Jiwa Karyawan Secara Umum}

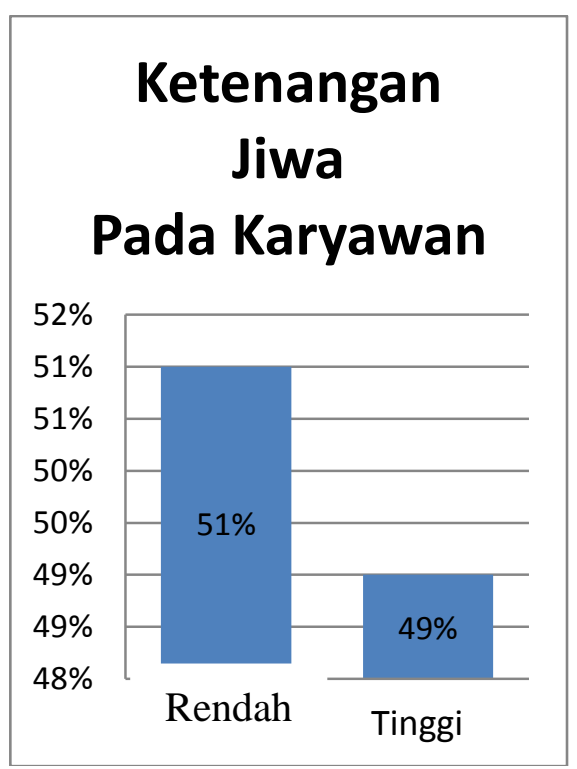

\section{b. Proses Analog Shocking Therapy sebagai Metode Katarsis terhadap Ketenangan Jiwa}

Berdasarkan data kuantitatif terkait ketenangan jiwa yang dilakukan dengan cara menyebarkan kuisioner kepada para karyawan sebanyak 29 responden menunjukkan hasil ketenangan jiwa yang dialami responden dalam kategori rendah sebanyak $51 \%$ dan yang memiliki
Analog Shocking Therapy sebagai Metode Katarsis terhadap Ketenangan Jiwa Pada Karyawan

ketenangan jiwa dalam kategori tinggi sebanyak 49\%. Hasil tersebut menunjukkan bahwa kebanyakan karyawan memiliki ketenangan jiwa yang rendah, dan untuk memperdalam data tersebut telah didapatkan data hasil dari wawancara sebagai data kualitatif yang dilakukan kepada dua informen untuk menggali informasi terkait ketenangan jiwa yang didapatkan setelah dilakukan terapi menggunakan Analog Shocking Therapy.

Wawancara yang dilakukan kepada informen bertujuan untuk menggali data secara lengkap untuk memperkuat data kuantitatif yang dilakukan dengan menyebarkan kuisioner sebelumnya pada karyawan yang bekerja di perusahaan roti. Dengan melakukan wawancara akan mempermudah peneliti untuk mengetahui bagaimana proses Analog Shocking Therapy terhadap ketenangan jiwa pada karyawan. Adapun data yang diperoleh adalah sebagai berikut:

Proses Terapi Menggunakan Analog Shocking Therapy adalah sebagai berikut:

Saat pelaksanaan terapi dengan responden pertama pada tanggal 30 Juni 2019 di Kota Jombang, responden merasakan kondisi yang dialaminya sedikit stres dan sedih. Adapun perasaan stres dan sedih tersebut jika diukur menggunakan skala 1-10 besarnya emosi negatif yang dirasakan responden berada diangka 8 . Kemudian responden diajak untuk duduk melakukan relaksasi dengan tarikan napas beberapa kali. ${ }^{20}$

Kemudian responden diajak untuk benar-benar mengikhlaskan permasalahan yang dialaminya dengan cara pasrah total kepada Allah. Langkah selanjutnya, responden diajak untuk melakukan relaksasi menggunakan tarikan napas sampai kondisinya tenang dan nyaman. Setelah responden merasakan kondisinya mulai tenang, responden diminta fokus. Terapis menggunakan analogi bola di

\footnotetext{
${ }^{20}$ Hasil wawancara dengan karyawan yang berinisial SH sebelum dilakukan terapi di kota Jombang pada tanggal 30 Juni 2019, pukul 15.00 WIB.
} 
Mohammad Aqil Baihaqi, Dian Siti Nurjanah, Medina Chodijah

kedua tangan terapis, lalu responden diajak untuk melakukan visualisasi terhadap bola yang terdapat di tangan terapis. Setelah responden dalam pikiranya sudah tergambar bola di kedua tangan terapis, kemudian responden dalam pikiranya diminta untuk menyalurkan semua emosi negatif berupa stres kerja dan rasa sedih yang dialaminya kedalam bola tersebut.

Ketika responden menyalurkan emosi negatifnya, maka bola yang ada di tangan terapis (dalam pikiran responden) juga ikut membesar. Setelah semua perasaan negatif tersebut disalurkan ke bola yang telah dibuat tadi hingga bolanya membesar. Baru langkah yang dilakukan selanjutnya adalah memperkecil bolanya. Tugas kita sebagai terapis adalah menekan sekuat tenaga mengecilkan bola tersebut. Semakin kita memperkecil tekanan bolanya maka semakin mengecil pula perasaan negatif yang dialami responden. Dan Saat kita memperkecil bolanya dan responden sedang fokus, barulah kita memberikan efek kejut secara tiba-tiba dengan cara memberikan tepukan tangan yang disertai dengan sugesti positif seperti kata-kata "sembuh, sehat, segar, nyaman, dan lainlain”.

Adapun yang dirasakan responden saat diberikan efek kejut disertai sugesti positif membuat responden terkaget seperti hilang fokus. Kemudian responden diminta untuk duduk tenang dan melakukan tarikan napas relaksasi untuk mendapatkan kenyamanan diri. Dan yang dirasakan responden setelah dilakukan terapi merasakan kondisinya lebih rilex, bahagia, dan lebih berpikiran positif. Dan setelah dilakukan terapi jika diukur dengan skala 10-1 responden pertama mengalami penurunan emosi di angka $5 .^{21}$

Saat pelaksanaan terapi dengan responden kedua, responden merasakan perasaan cemas dan adanya perasaan beban pikiran yang berat. Adapun perasaan

${ }^{21}$ Hasil wawancara dengan karyawan yang berinisial SH terhadap kondisi yang dirasakan setelah dilakukan terapi di kota Jombang pada tanggal 30 Juni 2019, pukul 15.20 WIB.
Analog Shocking Therapy sebagai Metode Katarsis terhadap Ketenangan Jiwa Pada Karyawan

tersebut jika diukur menggunakan skala 110 besarnya emosi negatif yang dirasakan responden berada diangka 9. Kemudian responden diajak untuk duduk melakukan relaksasi dengan tarikan napas beberapa kali. $^{22}$

Adapun langkah-langkah yang dilakukan saat terapi sama dengan responden sebelumnya. Dan jika dilihat dari wajah responden sebelum diterapi terlihat sedikit muram, yang menandakan adanya beban psikologis yang dialaminya. Dan ketika sudah dilakukan proses terapi, responden mengalami perasaan beban pikiran yang lebih ringan dan membangkitkan semangat. Hal tersebut tersebut juga terlihat dari perubahan bagian tubuh, terutama bagian wajah yang terlihat lebih ceriah dan tersenyum seakan-akan merasakan kondisi yang nyaman. Dan setelah dilakukan terapi jika diukur dengan skala 10-1 responden mengalami penurunan emosi di angka $6 .{ }^{23}$

\section{c. Analog Shocking Therapy sebagai metode katarsis terhadap ketenangan jiwa pada karyawan}

Setelah dilakukan penelitian menunjukkan bahwasanya Analog Shocking Therapy terbukti dapat mengatasi keresahan jiwa yang dialami karyawan. Adapun ketenangan jiwa yang didapatkan karyawan setelah dilakukan terapi menggunakan Analog Shocking Therapy yaitu Karyawan mampu mengatasi berbagai kesulitan dalam pekerjaanya, selalu berpikir positif terhadap rekan kerja, selalu membiasakan diri untuk berdzikir kepada Allah karena yang memberikan kesuksesan tidak lepas dari bantuan-Nya, lebih tenang dalam menjalankan pekerjaan, mampu mengendalikan rasa takut, khawatir, dan marah saat bekerja, lebih optimis, tidak mudah mengeluh, dan

\footnotetext{
22 Hasil wawancara dengan karyawan yang berinisial UA sebelum dilakukan terapi di kota Jombang pada tanggal 30 Juni 2019, pukul 16.00 WIB.

${ }^{23}$ Hasil wawancara dengan karyawan yang berinisial UA terhadap kondisi yang dirasakan setelah dilakukan terapi di kota Jombang pada tanggal 30 Juni 2019, pukul 16.30 WIB.
} 
Mohammad Aqil Baihaqi, Dian Siti Nurjanah, Medina Chodijah

memiliki semangat yang tinggi dalam mencapai target.

Selain itu ketenangan jiwa yang didapatkan yaitu lebih percaya diri dalam menjalankan pekerjaan dan mampu mengambil keputusan pada setiap aktivitas yang dilakukan dengan menentukan skala prioritas, lebih mudah untuk menyesuaikan diri dengan lingkungan kerja, tidak merasa lebih baik dengan rekan kerja lainya serta mampu bekerja secara tim, dan mampu mengatasi berbagai kekurangan diri serta mampu mengetahui berbagai potensi diri yang dapat membantu dalam meningkatkan karir.

\section{SIMPULAN}

Berdasarkan hasil penelitian yang dilakukan dapat diambil beberapa kesimpulan sebagai berikut.

Pertama, berdasarkan data kuantitatif terkait ketenangan jiwa yang dilakukan dengan cara menyebarkan kuisioner kepada para karyawan sebanyak 29 informan menunjukkan kondisi ketenangan jiwa yang dialami karyawan dalam kategori rendah sebanyak $51 \%$ dan yang memiliki ketenangan jiwa dalam kategori tinggi sebanyak $49 \%$. Hasil tersebut menunjukkan bahwa kebanyakan karyawan memiliki ketenangan jiwa yang rendah.

Kedua, saat proses penerapan Analog Shocking Therapy dalam pelaksanaan terapinya yaitu karyawan diajak untuk melakukan sebuah visualisasi dengan membuat perumpamaan benda berupa bola sebagai media untuk mentransfer emosi negatif yang dialaminya.

Ketiga, setelah dilakukan penelitian menunjukkan bahwasanya Analog Shocking Therapy terbukti dapat mengatasi keresahan jiwa yang dialami karyawan. Adapun ketenangan jiwa yang didapatkan karyawan setelah dilakukan terapi menggunakan Analog Shocking Therapy yaitu karyawan mampu mengatasi berbagai kesulitan dalam pekerjaanya, selalu berpikir positif terhadap rekan kerja, selalu membiasakan diri untuk berdzikir kepada Allah karena yang memberikan kesuksesan tidak lepas dari bantuan-Nya, lebih tenang dalam menjalankan
Analog Shocking Therapy sebagai Metode Katarsis terhadap Ketenangan Jiwa Pada Karyawan

pekerjaan, mampu mengendalikan rasa takut, khawatir, dan marah saat bekerja, lebih optimis, tidak mudah mengeluh, dan memiliki semangat yang tinggi dalam mencapai target.

\section{DAFTAR PUSTAKA}

Arfa, Muhamad. 2013. Pengaruh Teknik Relaksasi Nafas Dalam Terhadap Penurunan Nyeri Pada Pasien PostOperasi Appendisitis. Gorontalo: Universitas Negeri Gorontalo.

Aslihah, Noor 'Aini. 2015. Metode Penelitian Survey Terhadap Kinerja Karyawan Di Koperasi Syari'Ah Binama Semarang. Semarang: Universitas Islam Negeri Walisongo.

Daradjat, Zakiah. 1983. Kesehatan Mental. Jakarta: Gunung Agung.

Fatin, Ahmad Barozi dan Abu Azka. 2008. Penyakit Hati dan Penyembuhanya. Jogjakarta: Darul Hikmah.

Frager, Robert. 2002. Psikologi Sufi untuk Trnasformasi: Hati, Diri dan Jiwa. Jakarta: PT. Serambi Ilmu Semesta.

Nurindra, Yan. 2015. Modul Neo NLP Practitioner. Jakarta: Neo NLP Society.

Prasetya, Teddi. 2014. NLP The Art of Enjoying Life: Kiat Sederhana Mengelola Pikiran untuk Hidup Bahagia. Jakarta: Serambi Ilmu.

Siregar, Eric. 2014. Dahsyatnya kata-kata: Menghipnosis itu Sangat Mudah. Jakarta: Salaris Publisher.

Solihin, M. 2003. Tasawuf Tematik: Membedah Tema-tema Penting Tasawuf. Bandung: CV. Pusataka Setia.

Syakur, Abd. 2007. Metode Ketenangan Jiwa. Surabaya: Fakultas Dakwah IAIN Sunan Ampel.

Tika Saripah, dkk. 2017. Fungsi Zuhud Terhadap Ketenangan Jiwa. Bandung: Fakultas Ushuluddin UIN Sunan Gunung Djati Bandung.

Wahyuningsih, Sri. 2017. Teori Katarsis dan Perubahan Sosial. Madura: Fakultas Ilmu Sosial dan Ilmu Budaya Prodi Ilmu Komunikasi Universitas Trunojoyo Madura. 
Mohammad Aqil Baihaqi, Dian Siti Nurjanah, Medina Chodijah
Analog Shocking Therapy sebagai Metode Katarsis terhadap Ketenangan Jiwa Pada Karyawan

Yusuf, Syamsu. 2004. Mental Hygiene: Perkembangan Kesehatan Mental dalam Kajian Psikologi dan Agama. Bandung: Pustaka Bani Quraisy. 